УДК 793

\title{
ЗНАЧЕНИЕ И РОЛЬ ТВОРЧЕСКИХ СПОСОБНОСТЕЙ В ХОРЕОГРАФИЧЕСКОМ ИСКУССТВЕ
}

\section{Столяр О.Н.} магистр искусств, ст.преподаватель УО «Белорусский государственный университет культуры и искусств»

Статья посвящена значению и роли творческого подхода в хореографическом искусстве. В статье анализируется хореографическое искусство с точки зрения возможности развития и усовершенствования личности. Кроме того, рассматривается специфическая система ступенчатых творческих заданий как один способов развития творческих способностей студентов в вузе.

Ключевые слова: хореография, творчество, творческие способности, развитие творческих способностей.

\section{THE IMPORTANCE AND ROLE OF CREATIVITY IN CHOREOGRAPHIC ART}

Stoliar O.N.

The article is devoted to the importance and role of creativity in choreographic art. The report considers and analyses choreographic art as one of the opportunities for developing and improving personality. The system for performing specific tasks is based on well-established creativity methods and focused on the development of creative abilities.

Key words: choreography, creativity, creative abilities, development of creative abilities.

Individual personality differences have always been of considerable interest in the scientific community and have been one of the most complex and multifaceted. The primary guideline of scientific activity in rapidly changing modern realities focuses on individual harmonious development of personality. One of the central problems in the pedagogical and psychological sciences is the development of the 
creative abilities of the individual. The main concepts considered in this study are «Creativity», «Abilities», «Creative Abilities», «Development of Creative Abilities».

The philosophical dictionary gives such a definition. Creativity is «the highest form of universally understood creativity, immanently inherent in all levels of the hierarchy of being; contributes to the self-preservation and reproduction of things through the qualitative transformations of their structures» [1, p.820]. In the psychological dictionary, creativity understood as «practical or theoretical activity of a person in which new results arise (knowledge, solutions, methods of action, material products)» $[1, \mathrm{p} .820]$.

Dance is a type of art in which an artistic image created by movement, plasticity, facial expressions, gestures and postures of the human body. The art of dance in the modern language usually designated as choreography (from the Greek: Choreia - «dance» and graphic - «to write»). It should emphasise here that «choreography» includes several semantic meanings:

- dance recording through a specific system of conventional signs;

- a complex of music and dance;

- a synonym for the word «dance», which emphasises the motive principle;

- art of composing dances, numbers, performances and dance performances.

Turning to the origins of the dance, even in antiquity, people expressed strong emotions through movements. Furthermore, to this day, this subjective-emotional basis is preserved in choreography. For this reason, dance has always occupied an exceptional place in all historical periods, as it was part of social life, social rituals, and the everyday life of a person. Thanks to this close relationship, the dance changed, responding to each era's standards of tastes and aesthetics, reflecting the expression of the dance and the appearance of people and their manner of behaviour.

Like no other art form, choreography has great potential and opportunities for developing and improving personality, aesthetic, and physical progress. Dance combines a variety of means from musical-plastic, artistic-aesthetic, morally aesthetic and physical.

A distinctive feature of this type of art is that the content of the dance number or performance revealed through the plastic of the human body. «The plastic nature of dance through the peculiar and complex technique of this art reveals the inner world of a person, his lyrical-romantic relationships, actions, creates his external character, shows national, stylistic and historical affiliation» [2, p.35]. The artistic content of the dance art consists in revealing the content of the musical expressiveness of the human body. 
Today, the main varieties of choreographic art are classical, folk stage, variety, modern, ballroom dance (dancesport). Each of the listed dance systems has its vocabulary (movements, gestures, poses, plastic connection), expressive means and technique.

It is indisputable that choreography has formed its specific language, its original, unique to its opportunities for self-expression of a creative person.

In connection with certain specifics, there is no pronounced plot basis in the competitive ballroom dance. In other varieties of choreographic art (classical, pop, modern), the choreographer has the opportunity to choose any topic that can be embodied through dance to create a play or a completed performance, with specific images and plot.

The content in art is «an ideological, emotional, a sensually-shaped sphere of meaning and meaning, adequately embodied in an artistic form and having aesthetic value» [3, p. 258].

Artistic work is still one of the most mysterious aspects of human activity. Ancient thinkers in treatises devoted to studying the nature of artistic creativity focused their attention on the irrational and incomprehensible mechanisms of this process and the impossibility of revealing the laws that make the creative act possible.

It should note that creativity itself is the creation of what did not previously exist. Moreover, in this case, activities aimed at creating a new one cannot be measured by any criteria since the creative act is in the opposite direction from normativity. Of no minor importance for creativity is fantasy, which is a kind of synthesis of the emotional and the rational.

The pedagogy of choreographic art is a system of specific concepts with the help of which its essential characteristics and relationships revealed. This system includes the principle of integrity and focuses on developing the artistic and creative abilities of student-choreographers.

The problem of highlighting the components of creativity is still debatable in the scientific community. However, scientists agree that for the development of creativity, students need to develop the ability to solve creative problems to combine the incompatible, rely on students' subjective experience, and use heuristic methods for structuring students' creative activities. From this perspective, the creative activity of students-choreographers can be represented in the form of a system for performing specific creative tasks - ordered various interconnected creative tasks created based on well-established methods of creativity and aimed at creating, learning, 
transformation and use in a new quality of objects, situations, phenomena, focused on the development of creative abilities of students.

Let us turn to the conditions for the successful implementation of the process of creative development. Firstly, we are talking about the orientation of the process of preparing future teachers-choreographers for creative self-realization in the professional sphere. Students should be ready for the constant acquisition of new knowledge and skills, to increase the level of professionally personal qualities. Secondly, apply organized heuristic activity in the university educational process together with the teacher. Thirdly, to increase the role of students' independent work in the development of creativity, since this type of activity converts information into knowledge.

The choreographer, the creator of new choreographic works, in addition to professional knowledge and skills in the field of choreographic composition and performance, must have the abilities and knowledge of a playwright and director of the choreographic performance. It is the ability to think in choreographic images that distinguishes the choreographer from the playwright and director. The work of the choreographer is impossible without a constant search

Summarizing the above, it should be noted that today the development of creative abilities is one of the main goals of pedagogy. The development of students' creative abilities is realized as a result of intense activity. Among the components of creative abilities can be called creative thinking, creative imagination, the use of creative methods by students in the process of performing creative tasks. As for students-choreographers, their creative activity is the implementation of various creative tasks that have a logical structure and are built based on creative methods.

\section{References}

1. Большой энциклопедический словарь: философия, социология, религия, эзотеризм, политэкономия / Главн. науч. ред. и сост. С.Ю. Солодовников. - Минск: МФЦП, 2002. - 1008 с.

2. Громов, Ю.И. Танец и его роль в воспитании пластической культуры актера. 2-е изд., испр. - СПб.: Издательство «ПЛАНЕТА МУЗЫКИ»; Издательство «Лань», 2011. - 256 с.

3. Золкин, А.Л. Эстетика: учебник для студентов вузов, обучающихся по гуманитарно-социальным специальностям / А.Л.Золкин. - М.: ЮНИТИ-ДАНА, 2008. $-447 \mathrm{c}$. 